\title{
Sejarah Perkembangan Kota Semarang (Jawa Tengah) di Masa Lalu dan Dampak Kehadiran Polutan Nitrat Pada Airtanah di Masa Kini
}

\author{
History of the past development of the Semarang city(Central Java) \\ and its impact on nitrat pollutants presence in the groundwater \\ today
}

Sudaryanto dan Sunarya Wibawa

\begin{abstract}
ABSTRAK Sejarah perkembangan kota Semarang dimulai sejak abad ke-8 dan mulai dibangunnya perkantoran dan permukiman tahun 1705 terpusat di kota yang saat ini terkenal dengan kota lama Semarang. Periode berikutnya pembangunan perkantoran, permukiman dan vilavila yang cukup pesat tahun 1942-1976. Jumlah penduduk pada tahun 2010 akibat urbanisasi sebesar 1.527.433 jiwa, tingkat pertumbuhan penduduk 2,09\% pertahun dengan kepadatan penduduk rata-rata 4.087 jiwa $/ \mathrm{km}^{2}$. Permasalahannya apakah airtanah di kota Semarang yang termasuk kota tua dan merupakan wilayah urban telah terjadi kontaminasi nitrat. Hasil penelitian menunjukkan bahwa sebagian airtanah dangkal telah tercemari polutan nitrat dan tingginya nitrat tidak selalu berhubungan erat dengan umur permukiman dan kepadatan penduduk karena karakter litologi berperan sebagai penyerap atau meluluskan nitrat.
\end{abstract}

Kata Kunci : Kota Semarang, permukiman, polutan nitrat, penurunan kualitas airtanah.

$\begin{array}{ll}\text { Naskah masuk } & : \text { 1 Oktober } 2012 \\ \text { Naskah selesai revisi } & : \text { 19 Desember } 2012 \\ \text { Naskah siap cetak } & : \text { 20 Mei } 2013\end{array}$

Sudaryanto

Pusat Penelitian Geoteknologi LIPI

Komplek LIPI, Jl. Sangkuriang, Bandung 40135

E-mail : suda_020@geotek.lipi.go.id

Sunarya Wibowo

Pusat Penelitian Geoteknologi LIPI

Komplek LIPI, Jl. Sangkuriang, Bandung 40135

E-mail : wibowo.hadhi@gmail.com

\begin{abstract}
The history of Semarang City began in the 8th century which was marked by the construction of offices and settlements in 1705 centralized in the city nowdays well known as the old city of Semarang. The next period of development was during 1942-1976 marked by the vast development of office, settlement and villas. The population growth is $2.09 \%$ per annum and the population density is 4087 people $/ \mathrm{km}^{2}$. It is still unknown whether the groundwater in Semarang City, including the old city, has been contaminated by nitrate due to the urbanization effects. The result showed that most of shallow groundwater have been contaminated by nitrate pollutant. However, the high concentration of nitrate was not always correlated with the age of settlement and population density, because the local lithology hasa greater effect as the absorbent or permeating nitrate.
\end{abstract}

Keyword : Semarang city, settlement, nitrat pollutans, groundwater quality degradation.

\section{PENDAHULUAN}

Semarang merupakan ibukota provinsi Jawa Tengah yang perkembangannya dimulai abad ke8 Masehi dengan nama Pragota. Semarang berkembang dengan pesat sejak kedatangan armada Laksamana Cheng Ho bersandar di pelabuhan Simongan pada tahun 1405 dan mendirikan kelenteng yang saat ini disebut Kelenteng Sam Po Kong (Gedung Batu). Dalam kurun waktu 606 tahun, pelabuhan Simongan telah berubah menjadi daratan yang saat ini letaknya berada $5 \mathrm{~km}$ di sebelah selatan dari 
pelabuhan Tanjung Perak. Sejak Semarang di serahkan ke Belanda tahun 1705 oleh Paku Buwono I, Raja Mataram (Purwanto, 2005), mulailah dibangun permukiman-permukiman dan perkantoran yang saat ini lebih dikenal sebagai kota lama Semarang. Belanda mulai membangun vila-vila di daerah yang lebih tinggi di selatan kota Semarang mulai tahun 1942 dan dilanjutkan hingga jaman kemerdekaan tahun 1972.

Kota Semarang secara adminitrasi terdiri atas 16 kecamatan yang meliputi 177 kelurahan dengan luas wilayah keseluruhan $373,7 \mathrm{~km}^{2}$. Jumlah penduduk tahun 2010 adalah 1.527.433 jiwa, dengan tingkat pertumbuhan penduduk 2,09\% pertahun dengan kepadatan penduduk rata-rata 4.087 jiwa $/ \mathrm{km}^{2}$ (Bappeda dan BPS Kota Semarang, 2011). Peningkatan penduduk di kota Semarang salah satunya karena adanya urbanisasi. Urbanisasi adalah peningkatan proporsi populasi penduduk di dalam perkotaan dan sekitarnya yang berhubungan dengan perubahan penggunan lahan dari pertanian menjadi permukiman dan daerah komersiil (Hendrayana, 2010). Dampak negatip dari umur permukiman dan urbanisasi terhadap menurunnya kualitas airtanah, salah satunya oleh polutan nitrat, karena adanya konsentrasi limbah rumah tangga yang tidak dialirkan kepengolah limbah secara komunal, namun dialirkan melalui saluran sanitasi ke selokan dan tangki septik. Sumber pencemar yang berasal dari air limbah buangan tersebut akan meresap melalui pori-pori tanah masuk ke airtanah. Resapan yang berasal dari limbah rumah tangga (dosmestik) dan pertanian, akan mengakibatkan tingginya kandungan nitrat dalam airtanah (Kendall, 1988) dan nitrat merupakan unsur yang relative stabil dalam air. Min et. al (2003), menyatakan bahwa tingginya nitrat berkaitan dengan umur permukiman atau kota dan pencemaran nitrat pada airtanah umumnya tidak hanya terdapat di wilayah perkotaan atau di kota-kota besar tetapi diketemukan dilingkungan permukiman- permukiman. Permasalahannya apakah airtanah di Semarang yang termasuk kota tua dan merupakan wilayah urban telah terjadi kontaminasi nitrat.

Tujuan penelitian ini adalah untuk mengetahui sebaran kandungan polutan nitrat dalam airtanah dangkal di Semarang dan apakah tingginya polutan nitrat berhubungan dengan umur permukiman, kepadatan penduduk dan kondisi litologi setempat. Langkah-langkah yang dilakukan dalam penelitian ini dengan melakukan pendataan serta pengukuran di lapangan dan pengambilan conto airtanah untuk keperluan analisis kimia di laboratorium. Hasilnya dilakukan analisis hubungan antara kandungan nitrat dengan umur permukiman, kepadatan penduduk akibat urbanisasi dan kondisi litologi setempat.

Hasil dari penelitian ini diharapkan dapat sebagai acuan bagi masyarakat maupun pemerintah daerah dalam pengelolaan sumberdaya airtanah maupun limbah rumah tangga (domestik) menuju yang lebih baik.

\section{LOKASI PENELITIAN}

Lokasi penelitian di Kota Semarang, secara geografis terletak $6^{\circ} 56^{\prime}-7^{\circ} 07^{\prime}$ LS dan $110^{\circ} 16^{\prime}$ $110^{\circ} 30^{\prime}$ BT. Secara administratif di sebelah utara dibatasi oleh Laut Jawa, di sebelah selatan oleh Kabupaten Semarang, di sebelah barat oleh Kabupaten Kendal dan di sebelah timur oleh Kabupaten Demak. Ditinjau dari keadaan topografi daerah Semarang pada bagian utara hingga pantai merupakan dataran rendah, sedangkan di bagian selatan merupakan perbukitan, kota ini memiliki dua daerah yang secara geografis keadaannya berlawanan, di bagian utara berupa dataran rendah sedangkan di bagian selatan mempunyai ketinggian $270 \mathrm{~m}$. Kota Semarang meliputi luas wilayah $373,7 \mathrm{~km}^{2}$, daerah penelitian secara administratif merupakan Provinsi Jawa Tengah (Gambar 1). 


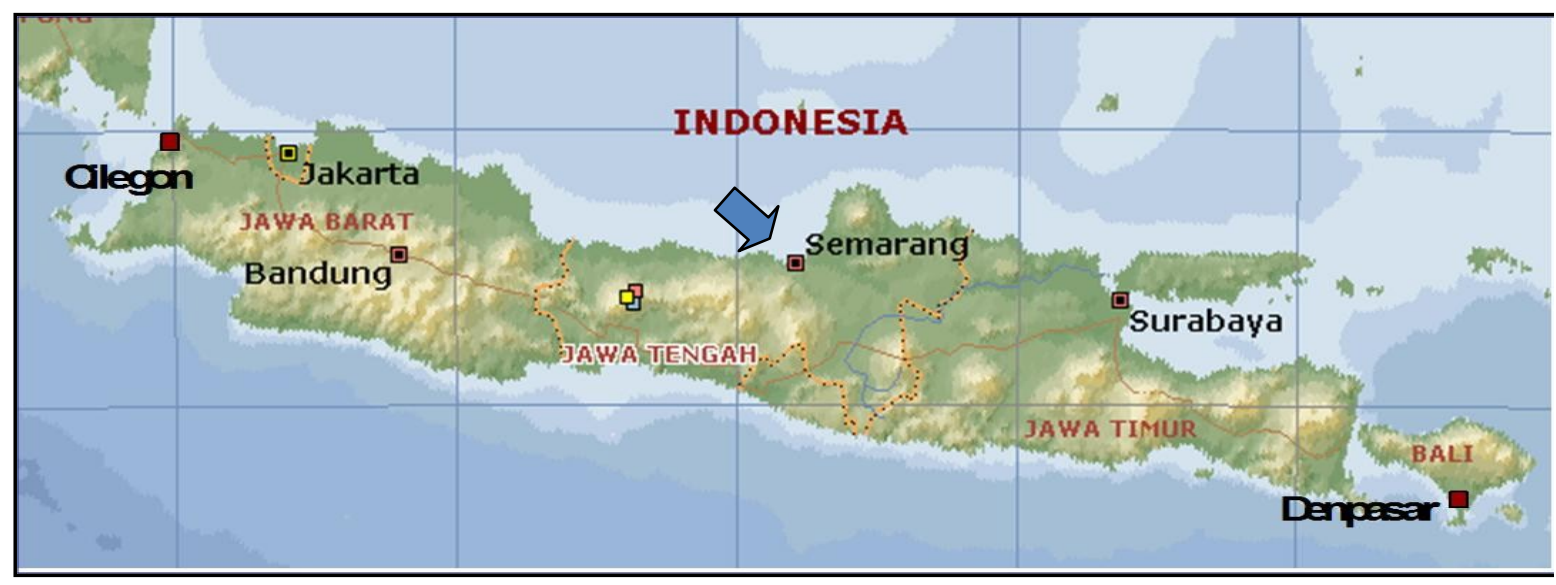

Gambar 1. Lokasi Penelitian Semarang.

\section{Hidrogeologi}

Wilayah kota Semarang mencerminkan bentang alam berupa dataran rendah pantai dan daerah perbukitan, dengan ketinggian berkisar antara 0 $270 \mathrm{~m}$ dml. Morfologi dataran rendah, mempunyai ketinggian antara 0-50 m dpl, yang terbentang luas di daerah dataran pantai mulai dari Kendal di bagian barat, Semarang di bagian tengah hingga Demak di bagian timur. Pada morfologi dataran ini tertutupi endapan aluvium, yang terdiri dari endapan sungai, endapan delta Garang dan endapan pantai. Endapan aluvium

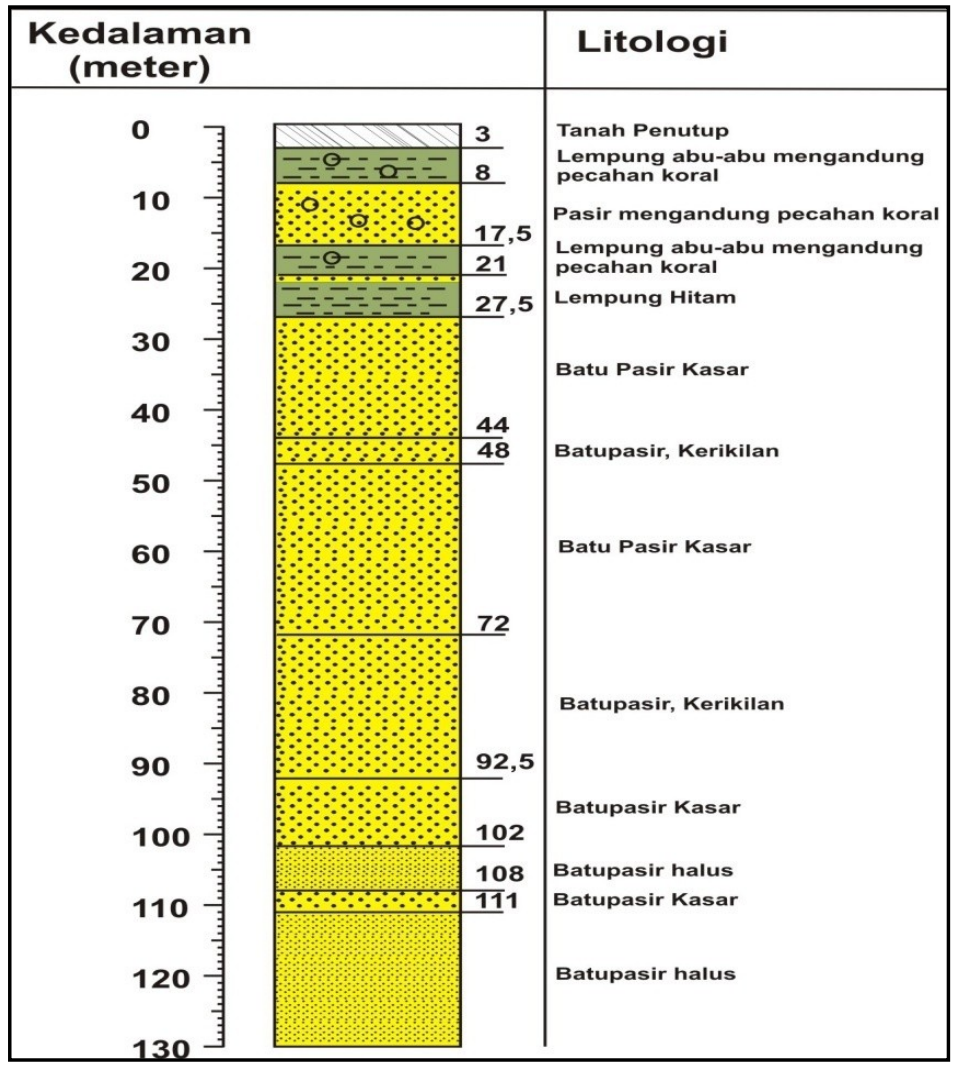

Gambar 2. Penampang lubang Bor di Masjid Baiturahman, Simpang Lima Semarang (Arifin dan Wahyudin, 2000). 
merupakan material-material lepas, berupa pasir, lanau, lempung, kerikil dan kerakal. Morfologi perbukitan yang terletak di bagian selatan kota Semarang mempunyai ketinggian berkisar antara 50-270 m dpl. Morfologi perbukitan ini merupakan Formasi Damar yang terdiri dari batupasir, breksi, konglomerat dan tufa (Sihwanto dan Iskandar, 2000).

Sihwanto dan Iskandar (2000), menyatakan bahwa sistem akuifer airtanah di dataran Semarang terdiri atas kelompok akuifer :

1. Akuifer Endapan Kuarter, akuifer ini terdapat di dataran rendah. Penyebarannya tidak menerus kearah horisontal, dengan variasi litologi dan di beberapa tempat dijumpai adanya lebih dari satu akuifer, dan setiap lapisan akuifer dipisahkan oleh lapisan yang kelulusanya relatif rendah. Gambar 2, adalah penampang lubang bor yang terletak pada endapan Kuarter, litologinya berupa tanah penutup, lempung abu-abu mengandung koral dengan ketebalan antara 1-8 $\mathrm{m}$, dibawahnya berupa pasir mengandung koral, lempung abuabu mengandung pecahan koral, dan lempung hitam yang berperan sebagi pembatas antara airtanah tidak tertekan dan airtanah tertekan. Kedalaman akuifer tidak tertekan berkisar antara 0-17,5 $\mathrm{m}$ di bawah muka tanah setempat (bmt) sedangkan untuk akuifer tertekan berkisar antara 27,5-130 m bmt, sebaran akuifer endapan Kuarter di bagian barat mulai Bulu dan Kalibanteng sedangkan di bagian timur sampai daerah Tambaklorok.

2. Akuifer Formasi Damar, penyebarannya di daerah selatan Semarang mulai dari perbukitan Candisari dan di Simongan

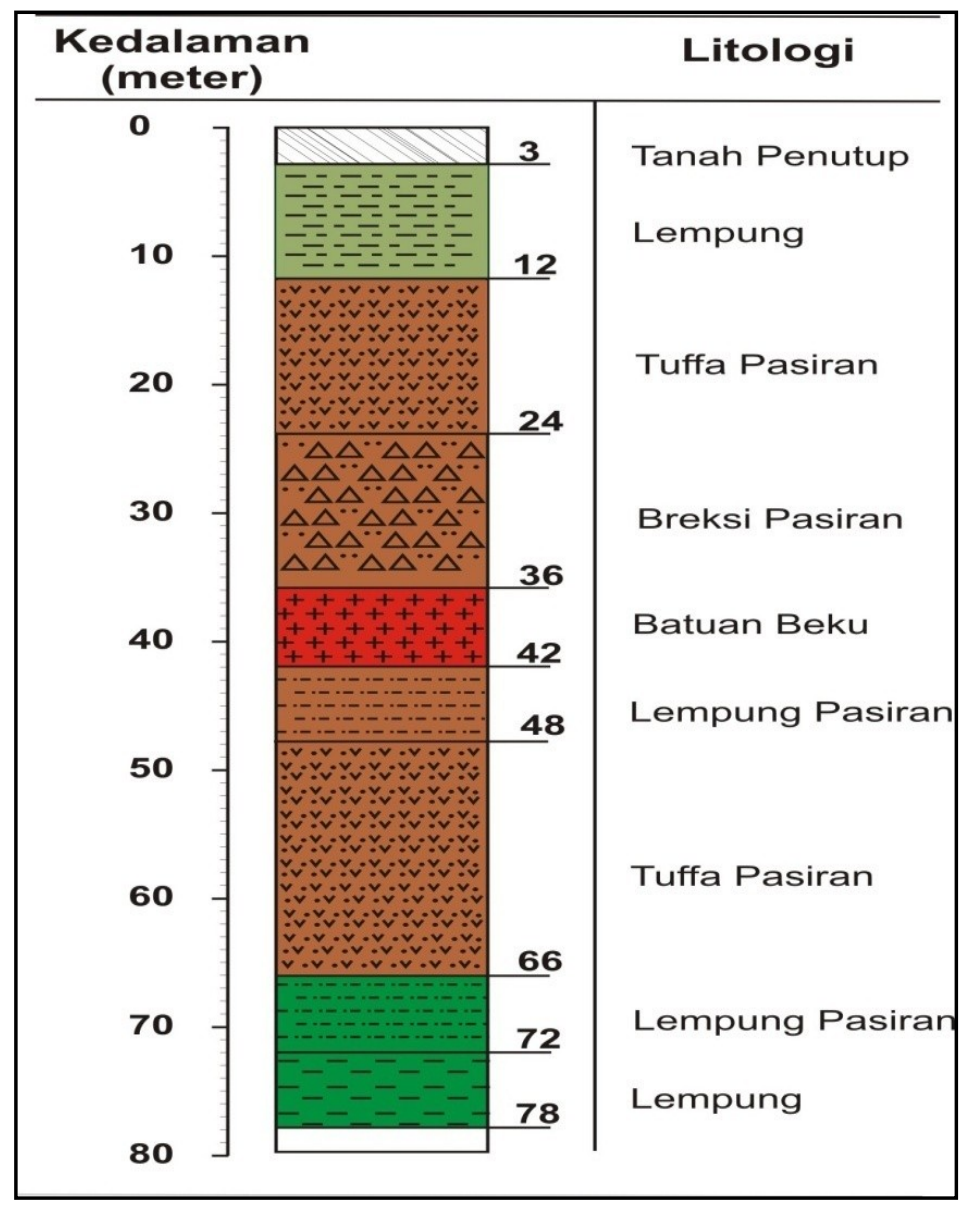

Gambar 3. Penampang lubang Bor di PT. Wahyu Utomo, Semarang (Arifin dan Wahyudin, 2000). 
3. (Sampokong). Gambar 3, adalah penampang lubang bor yang terletak pada Formasi Damar, litologinya terdiri dari bagian atas berupa tanah penutup, lempung, tufa pasiran, breksi pasiran, batuan beku dan lempung pasiran. Kedudukan akuifer tidak tertekan di kedalaman antara 3-24 m bmt, akuifer tertekan di kedalaman 42-66 m.

\section{TINJAUAN PUSTAKA}

Nitrat dalam air berkaitan erat dengan siklus nitrogen di alam. Dalam siklus tersebut nitrat dapat terjadi dari $\mathrm{N}_{2}$ dan dari oksida $\mathrm{NO}_{2}^{-}$oleh bakteri dari kelompok Nitrobacter (Effendi, 2003). Sumber pencemaran nitrat pada air tanah berasal dari permukiman penduduk yang menggunakan tangki septik, kakus dan sumur injeksi (Min at al., 2003). Notodarmojo (2005), menyatakan bahwa tingginya pencemaran airtanah akibat tangki septik dan kakus di Indonesia masih cukup tinggi, karena sistem penyaluran dan pengolahan limbah domestik secara komunal masih langka (hanya melayani kurang dari $1 \%$ penduduk), sehingga penggunaan tangki septik dan kakus sebagai tempat pembuangan limbah masih dominan. Umezawa et. al (2008), menyatakan bahwa sumber pencemar pada airtanah di kota-kota besar termasuk Jakarta karena buangan limbah domestik dan saluran buangan dari permukiman.

Menurut Hammer dan MacKichan (1981), tingginya konsentrasi Nitrat di daerah perkotaan disebabkan oleh besarnya masukan limbah rumah tangga (limbah domestik), yang dipengaruhi dengan tingkat kepadatan septik tank. Keberadaan nitrat dalam airtanah disebabkan oleh aktivitas manusia seperti penggunaan pupuk buatan, lindihan sampah dari tempat pembuangan akhir (Sudaryanto dan Suherman, 2009), dimana pemicunya adalah air lindi yang masuk ke badan airtanah. Tingginya Nitrat di perkotaan disebabkan oleh besarnya masukan limbah rumah tangga yang dipengaruhi oleh tingkat kepadatan rumah-rumah penduduk, umur suatu pemukiman dimana berlaku semakin tua umur suatu pemukiman semakin besar konsentrasi nitrat di kawasan tersebut (Min at al., 2003). Kadar nitrat yang tinggi dapat bersifat toksik dan dapat mengganggu kesehatan manusia, Notodarmojo (2005) menyatakan bahwa standar maksimum kandungan nitrogen-nitrat $\left(\mathrm{NO}_{3}-\mathrm{N}\right)$ dalam air minum adalah $10 \mathrm{mg} / 1$ (45 mg/l bila dinyatakan sebagai nitrat). Konsentrasi nitrat yang tinggi bagi kesehatan terutama bagi bayi dapat menyebabkan apa yang disebut "blue baby", yaitu terjadinya warna kebiru-biruan pada bayi karena kekurangan oksigen. Selain itu, kandungan nitrat yang tinggi juga mempunyai peran penting dalam pembentukan senyawa yang dapat menyebabkan penyakit kanker .

Nitrat $\left(\mathrm{NO}_{3}{ }^{-}\right)$dan nitrit $\left(\mathrm{NO}_{2}^{-}\right)$merupakan ion-ion anorganik bagian dari siklus nitrogen. Mikroba di tanah atau pada air mengurai limbah yang mengandung nitrogen organik menjadi ammonium $\left(\mathrm{NH}_{4}\right)$ yang kemudian dioksidasikan menjadi nitrat dan nitrit. Keterjadian penguraian tersebut menyebabkan nitrat merupakan senyawa yang paling sering ditemukan dalam airtanah (Umezawa et. al, 2008). Disebutkan pula bahwa sumber utama ammonium $\left(\mathrm{NH}_{4}\right)$ berasal dari Tanki septik, Kakus dan tempat pembuangan sampah. Tang et al (2004), menyatakan bahwa polutan didalam airtanah dengan sebaran tinggi di kota-kota besar didunia adalah nitrat dan nitrit dan senyawa nitrat di dalam tanah mudah berimigrasi ke airtanah dalam kondisi alami, pada suhu dan tekanan normal amonia berada dalam bentuk gas dan membentuk kesetimbangan dengan gas amonium ditunjukkan dalam persamaan reaksi sebagai berikut :

$$
\mathrm{NH}_{3}+\mathrm{H}_{2} \mathrm{O} \leftrightarrow \mathrm{NH}_{4}^{+}+\mathrm{OH}^{-}
$$

Nitrifikasi merupakan proses oksidasi ammonia $\left(\mathrm{NH}_{3}\right)$ menjadi nitrit dan nitrat, proses ini penting dalam siklus nitrogen dan berlangsung pada kondisi aerob. Oksidasi ammonia menjadi nitrit dilakukan oleh Nitrosomonas, sedangkan oksidasi nitrit menjadi nitrat dilakukan oleh bakteri Nitrobacter. Nitrat merupakan salah satu parameter pencemar yang berasal dari limbah domestik (rumah tangga). Hal ini dikarena ammoniak $\left(\mathrm{NH}_{3}\right)$ yang dihasilkan dari limbah tersebut melalui bakteri diubah menjadi nitrat dengan reaksi sebagai berikut : 
Reaksi nitrifikasi :

$2 \mathrm{NH}_{3}+3 \mathrm{O}_{2}$ Nitrosomonas/Nitrosococcus $==\rightarrow 2 \mathrm{HNO}_{2}+2 \mathrm{H}_{2} \mathrm{O}+158$ kilokalori

(Ammonia) (bakteri nitrit) (asam nitrit)

Reaksi denitrifikasi :

$\begin{aligned} 2 \mathrm{HNO}_{2}+\mathrm{O}_{2} \underline{\text { Nitrobacter }==}= & =\rightarrow 2 \mathrm{HNO}_{3}+36 \text { kilokalori } \\ & \text { (asam nitrat) }\end{aligned}$

Asam nitrat yang terbentuk mengalami ionisasi seperti reaksi di atas sehingga terbentuk ion nitrat.

\section{METODE PENELITIAN}

Guna mengetahui sebaran kandungan polutan nitrat dalam airtanah dangkal di Semarang dan apakah tingginya polutan nitrat berhubungan dengan umur permukiman, kepadatan penduduk dan kondisi litologi setempat. Untuk mengetahui hal tersebut dilakukan pengambilan conto airtanah tidak tertekan yang di fokuskan di pusat kota Semarang Lama yang dahulunya sebagai pusat pemerintahan Belanda dan permukiman yang dibangun sejak tahun 1705 (Purwanto, 2005) yang diyakini merupakan permukiman tertua yang ada hingga saat ini, serta permukiman dan vila-vila yang dibangun tahun 1942 di sebelah selatan kota. Di pusat kota Semarang meliputi 9 Kecamatan, yaitu Kecamatan: Semarang Tengah, Semarang Barat, Semarang

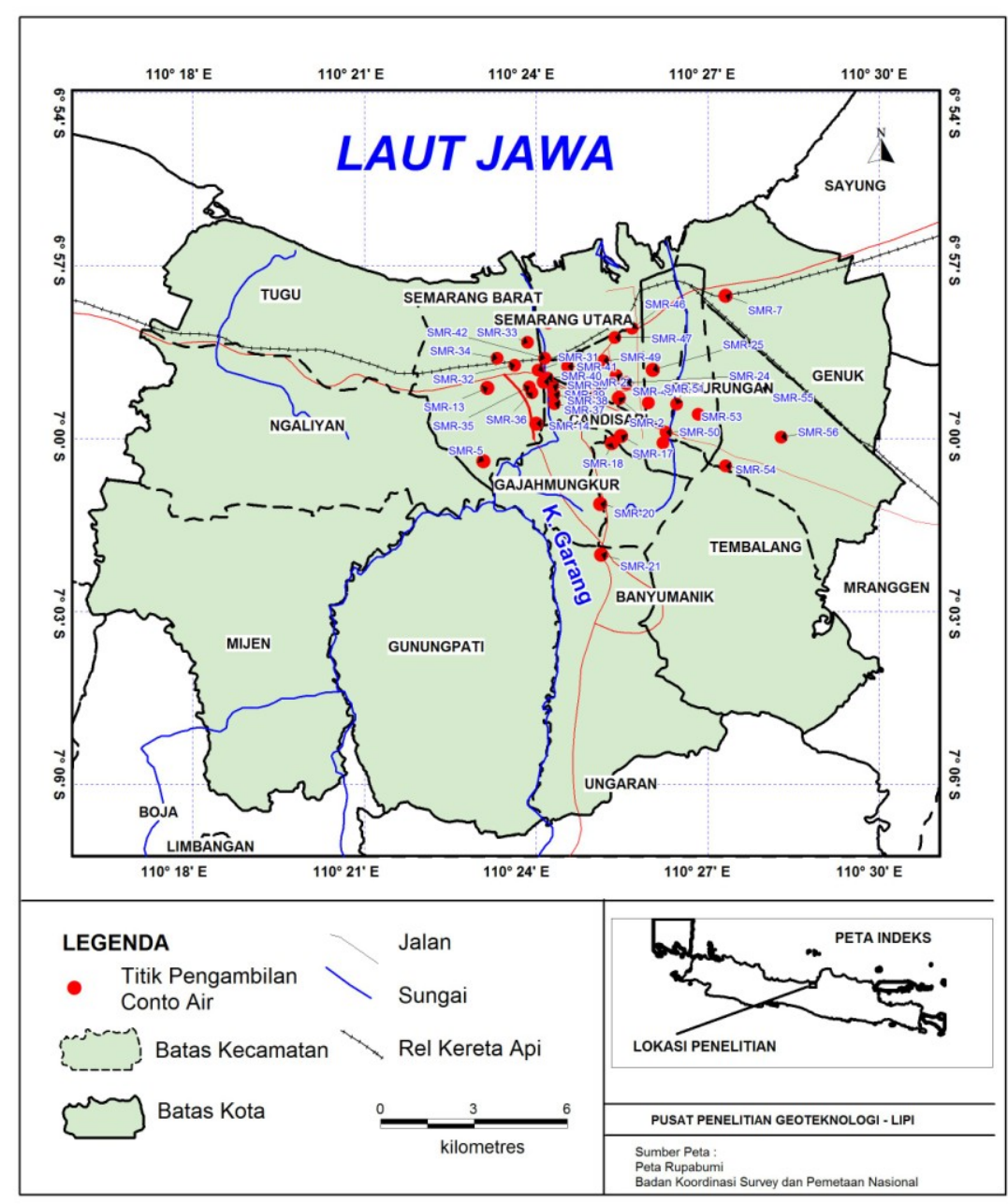

Gambar 4. Lokasi pengambilan conto airtanah tidak tertekan (sumur gali). 
Timur, Semarang Utara, Semarang Selatan, Candisari, Kecamatan Gayamsari, Gajah Mungkur dan Banyu Manik. Di 9 kecamatan tersebut mempunyai tingkat kepadatan penduduk yang cukup tinggi dibanding kecamatan diluar pusat kota yaitu 7,357 jiwa per $\mathrm{km}^{2}-14,391$ jiwa per $\mathrm{km}^{2}$.

Data yang diambil secara langsung di tempat lokasi penelitian mencakup data kondisi lingkungan sumur gali. Alat yang digunakan untuk pengambilan conto air adalah water sampler vertical yang terbuat dari fiber glass, dengan volume sekitar $600 \mathrm{ml}$. Parameter kimia maupun fisika $(\mathrm{pH}$, DHL, dan temperatur) pengukurannya dilakukan di lapangan dengan menggunakan alat water quality checker merk Horiba tipe U 10. Untuk menentukan posisi digunakan GPS (Global Positioning System). Jumlah seluruh conto airtanah adalah 42 tertera pada Gambar 4 dan Tabel 1. Setiap conto airtanah dilakukan analisis kimia kandungan polutan nitrat, dengan alat Spektrofotometer sinar tampak, Shimazu. Selanjutnya melakukan pengolahan data, tentang kondisi airtanah di Semarang sehingga dapat dihasilkan sebagai dasar dalam penentuan daerah mana yang telah mengalami pencemaran nitrat yang mengakibatkan penurunan kualitas airtanah.

\section{HASIL DAN PEMBAHASAN}

Zat pencemar (pollutant) dapat didefinisikan sebagai zat kimia (cair, padat maupun gas), baik yang berasal dari alam yang kehadirannya dipicu oleh kegiatan manusia (anthropogenic origin) yang telah diidentifikasi mengakibatkan efek yang buruk bagi kehidupan manusia atau lingkungannya (Notodarmojo, 2005). Pengertian kontaminan sama dengan seperti zat pencemar, hanya saja efek negatif atau dampaknya secara nyata terhadap manusia dan lingkungannya belum teridentifikasi secara jelas.

Pengamatan beberapa sumur gali (Tabel 1) di dataran Semarang pada bulan Mei 2010 menunjukkan elevasi muka air tanah dengan kisarannya antara $-0,30 \mathrm{~m}$ hingga $-17,46 \mathrm{~m}$ dari muka tanah. Secara umum di daerah Semarang bagian utara kedalaman muka air tanah antara $0,30 \mathrm{~m}$ hingga $-1,89 \mathrm{~m}$, sedangkan yang mempunyai muka air tanah terdalam $-17,46 \mathrm{~m}$
(SMR-20) terletak di Jangli Tlawah, Karangayar lokasi ini berada di perbukitan sebelah selatan kota Semarang.

Tiga parameter yang diukur di lapangan (Tabel 1) yaitu temperatur, daya hantar listrik (DHL), dan derajat keasaman $(\mathrm{pH})$. Data yang diperoleh menunjukkan bahwa temperatur berkisar antara $22,7{ }^{\circ} \mathrm{C}$ hingga $31,2{ }^{\circ} \mathrm{C}$, DHL antara $250 \mu \mathrm{S} / \mathrm{cm}$ hingga $4450 \mu \mathrm{S} / \mathrm{cm}$ terendah di SMR-36 Jl. Puspanjolo Tengah di sekitar perbukitan dan nilai tertinggi terdapat di lokasi SMR-51 yakni di J1. Jl. Unta Raya. Derajat keasaman $\mathrm{pH}$ berkisar antara 6,06 hingga 8,18. Pengukuran DHL dilakukan setiap kedalaman $0,5 \mathrm{~m}$, namun tidak memperlihatkan perbedaan nilai DHL, ini mencerminkan bahwa di wilayah penelitian tidak terdapat stratifikasi air artinya air yang bersangkutan berasal dari satu sumber (tidak berlapis). Ketebalan (ketinggian) air pada sumur yang diamati berkisar antara 1,40 m hingga 6,8 m. Paling tebal terdapat di Jl. Sindang Gua dan yang paling tipis terdapat di Jl. Erowati Raya 4.

Hasil analisis laboratorium parameter kimia nitrat $\left(\mathrm{NO}_{3}-\mathrm{N}\right)$, apabila dicermati di beberapa lokasi penelitian memperlihatkan nilai nitrat yang melebihi ambang batas. Kandungan nitrat yang melampaui ambang batas $(10 \mathrm{mg} / \mathrm{L})$ terdapat di empat lokasi yaitu SMR-13, SMR-20, SMR-21, dan SMR-25 yang terdapat pada Formasi Damar (Gambar 4 dan 6). Dua sumur gali yang sudah lama tidak dimanfaatkan air tanahnya mempunyai kandungan nitrat tertinggi 13,25 $\mathrm{mg} / \mathrm{l}$ dengan $\mathrm{pH}$ 6,06 (Tabel 1) pada kedalaman muka air tanah 17,46 mdmt (meter dari muka tanah) ditemui di daerah Jangli Tlawah, Karangayar (SMR-20), serta sumur gali di komplek Sapta Marga (SMR-21) dengan $\mathrm{pH}$ 6,28 pada kedalaman muka airtanah 1,49 mdmt, kandungan nitrat 12,09 mg/l. Kedua sumur ini sudah lama tidak digunakan untuk kebutuhan sehari-hari sehingga terjadi akumulasi dari sumber pencemar disekitarnya. Kandungan nitrat tinggi $12,11 \mathrm{mg} / \mathrm{l}$ terdapat di Karang Sawo sebelah barat Klenteng Sampokong (SMR-13) dengan $\mathrm{pH}$ 7,01 pada kedalaman muka air tanah 1,44 mdmt, dan tingginya kandungan nitrat nampak dari dinding sumur adanya rembesan air dari permukiman padat di sebelah selatan dengan posisi lebih tinggi dari lokasi sumur SMR-13. 
Tabel 1. Nama lokasi pengambilan conto airtanah dan hasil pengamatan lapangan.

\begin{tabular}{|c|c|c|c|c|c|c|c|c|c|}
\hline No & Nama lokasi & $\begin{array}{l}\text { Jenis } \\
\text { Sumur }\end{array}$ & $\begin{array}{l}\text { Kode } \\
\text { Conto }\end{array}$ & $\begin{array}{c}\text { Muka Air } \\
\text { Tanah } \\
\text { (m) }\end{array}$ & $\begin{array}{c}\text { Kedalaman } \\
\text { Conto Air } \\
\text { (m) }\end{array}$ & pH & $\begin{array}{c}\text { DHL } \\
(\mu \mathrm{S} / \mathbf{c m})\end{array}$ & $\begin{array}{c}\text { Temp. } \\
\left({ }^{0} \mathrm{C}\right)\end{array}$ & $\begin{array}{l}\mathrm{NO}_{3}{ }^{-\mathrm{N}} \\
(\mathrm{mg} / \mathrm{L})\end{array}$ \\
\hline 1 & Citra Land Simpang Lima & Sumur Gali & SMR-2 & 0,73 & 0.8 & 7,37 & 1810 & 23,7 & 0,84 \\
\hline 2 & Kimia Farma & Sumur Gali & SMR-5 & 0,8 & 1.50 & 7,33 & 501 & 27,4 & 6,57 \\
\hline 3 & PRPP II Rumah Diesel & Sumur Gali & SMR-6 & 18,71 & 20 & 8,15 & 4450 & 31,7 & 0,17 \\
\hline 4 & LIK Kaligawe & Sumur Gali & SMR-7 & 0,45 & 0.55 & 8,18 & 268 & 31,2 & 3,98 \\
\hline 5 & Karang Sawo & Sumur Gali & SMR-13 & 1,44 & 1.60 & 7,01 & 731 & 28,4 & 12,11 \\
\hline 6 & Sekitar Sam Po Kong & Sumur Gali & SMR-14 & 1,53 & 1.60 & 7,7 & 836 & 26,5 & 1,09 \\
\hline 7 & J1. Peleburan Raya & Sumur Gali & SMR-17 & 3,5 & 10 & 6.96 & 685 & 23,9 & 4,75 \\
\hline 8 & Kp. Genuk Krajan & Sumur Gali & SMR-18 & 1,78 & 1.90 & 6.93 & 723 & 26,8 & 4,35 \\
\hline 9 & Kp. Tegal Sari, Atom & Mata Air & SMR-19 & 0 & 0 & 7,07 & 414 & 28,6 & 11,16 \\
\hline 10 & $\begin{array}{l}\text { Jangli Tlawah, Karang } \\
\text { Anyar Gunung }\end{array}$ & Sumur Gali & SMR-20 & 17,46 & 18.00 & 6,06 & 338 & 29,5 & 13,25 \\
\hline 11 & $\begin{array}{l}\text { Kompl. Sapta Marga, } \\
\text { Jatigalek }\end{array}$ & Sumur Gali & SMR-21 & 1,49 & 1.60 & 6,28 & 255 & 28,9 & 12,09 \\
\hline 12 & JL. Taman Pekuncen & Sumur Gali & SMR-22 & 0,48 & 0.60 & 7,56 & 1280 & 29,6 & 4,57 \\
\hline 13 & Kp. Kepundan Utara & Sumur Gali & SMR-23 & 1,89 & 2.00 & 7,51 & 1050 & 28,5 & 0,98 \\
\hline 14 & JL, Karang Wulan Barat & Sumur Gali & SMR-24 & 0,57 & $0 . .70$ & 7,56 & 852 & 29,6 & 3,94 \\
\hline 15 & Petelan Selatan & Sumur Gali & SMR-25 & 0,55 & 0.70 & 7,26 & 657 & 29 & 10,61 \\
\hline 16 & Jln Madukoro I & Sumur Gali & SMR-31 & 0,80 & 3,7 & 7,22 & 607 & 27,1 & 2,65 \\
\hline 17 & Jln Damarwulan I & Sumur Gali & SMR-32 & 0,74 & 2,0 & 7,20 & 556 & 27,8 & 3,93 \\
\hline 18 & Jl Dworowati III & Sumur Gali & SMR-33 & 0,58 & 2,5 & 7,37 & 1080 & 27,5 & $\mathrm{ttd}$ \\
\hline 19 & Jl Ajasmoro Tengah IV & Sumur Gali & SMR-34 & 1,10 & 2,55 & 7,08 & 724 & 28,1 & $\mathrm{ttd}$ \\
\hline 20 & Jl. Puspanjolo Tengah VII & Sumur Gali & SMR-35 & 0,86 & 3,10 & 7,13 & 935 & 27,7 & $\mathrm{ttd}$ \\
\hline 21 & Jl Puspanjolo Tengah & Sumur Gali & SMR-36 & 3,50 & 3,50 & 7,30 & 435 & 28,2 & $\mathrm{ttd}$ \\
\hline 22 & Jl Suyudono, Lab. Undip & Sumur Gali & SMR-37 & 1,55 & 3,1 & 7,09 & 579 & 28,1 & 0,22 \\
\hline 23 & Cokroaminoto (Kom AD) & Sumur Gali & SMR-38 & 0,98 & 1,80 & 7,20 & 778 & 27,8 & 1,73 \\
\hline 24 & Jl. Bulu Stalan & Sumur Gali & SMR-39 & 0,98 & 2,05 & 6,97 & 1260 & 28,5 & $\mathrm{ttd}$ \\
\hline 25 & Jl. Bulus Talang Gang II & Sumur Gali & SMR-40 & 0,40 & 1,95 & 7,31 & 770 & 28,7 & ttd \\
\hline 26 & J1. Sadewa & Sumur Gali & SMR-41 & 0,70 & 2,20 & 7,38 & 776 & 29,5 & $\mathrm{ttd}$ \\
\hline 27 & Jl. Erowati Raya 4(a) & Sumur Gali & SMR-42 & 0,30 & 1,40 & 7,50 & 606 & 27,5 & $\mathrm{ttd}$ \\
\hline 28 & Jl. Erowati Raya 4(b) & Sumur Gali & SMR-43 & 0,30 & 3,50 & 7,28 & 789 & 28,6 & $\mathrm{ttd}$ \\
\hline 29 & J1 Biroto Jaya Barat & Sumur Gali & SMR-44 & 0,50 & 4,00 & 7,49 & 1250 & 28 & $\mathrm{ttd}$ \\
\hline 30 & Kel. Karang Turi Bld & Sumur Gali & SMR-45 & 0,90 & 2,50 & 7,68 & 845 & 28 & $\mathrm{ttd}$ \\
\hline 31 & Jl. Perkutut, G. Blenduk & Sumur Gali & SMR-46 & 0,60 & 2,00 & 7,60 & 1200 & 29,3 & $\mathrm{ttd}$ \\
\hline 32 & Jl. Pemuda Metro & Sumur Gali & SMR-47 & 0,60 & 1,50 & 7,75 & 536 & 28,9 & 2,21 \\
\hline 33 & Kl. Mawelan & Sumur Gali & SMR-48 & 1,55 & 3,50 & 7,50 & 1120 & 28,4 & 0,02 \\
\hline 34 & J1 Depok Pegadaian & Sumur Gali & SMR-49 & 0,82 & 1,60 & 7,46 & 591 & 28,1 & 0,80 \\
\hline 35 & Panda Lemper, Jarum & Sumur Gali & SMR-50 & 3,20 & 2,50 & 7,38 & 793 & 29,2 & 0,91 \\
\hline 36 & Jl. Unta Raya & Sumur Gali & SMR-51 & 0,70 & 1.50 & 7,44 & 1800 & 29,1 & $\mathrm{ttd}$ \\
\hline 37 & JL. Kanal Timur & Sumur Gali & SMR-52 & 2,05 & 3,50 & 7,29 & 804 & 27,9 & 2,40 \\
\hline 38 & Jl. Gajah Timur IV & Sumur Gali & SMR-53 & 1,05 & 2.00 & 7,53 & 1520 & 29,1 & $\mathrm{ttd}$ \\
\hline 39 & JL. Sendang Guo & Sumur Gali & SMR-54 & 0,92 & 6,80 & 7,30 & 745 & 28,9 & 1,69 \\
\hline 41 & Sumur Syuhada & Sumur Gali & SMR-55 & 0,95 & 3,80 & 7,30 & 1310 & 29,1 & 176 \\
\hline 42 & Sumur Mbah Kliwon & Sumur Gali & SMR-56 & 0,84 & 3,40 & 7,80 & 953 & 28,7 & $\mathrm{ttd}$ \\
\hline
\end{tabular}




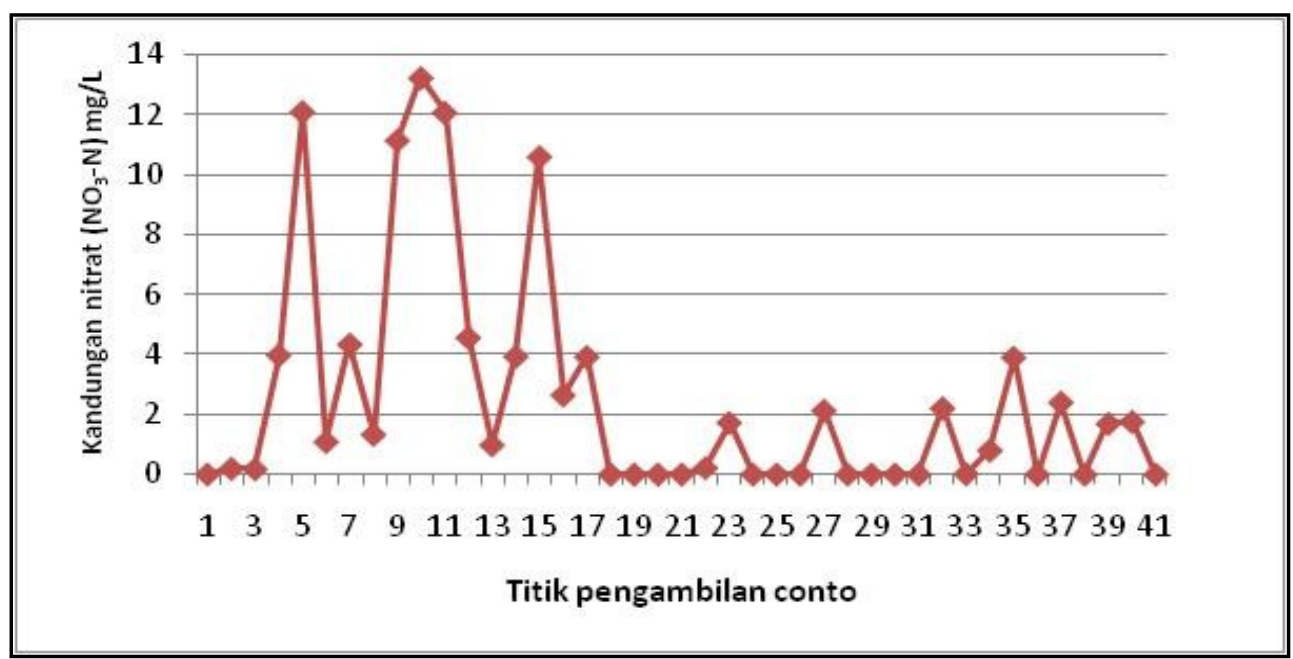

Gambar 5. Grafik hasil analisis kandungan nitrat pada airtanah dangkal di Semarang.

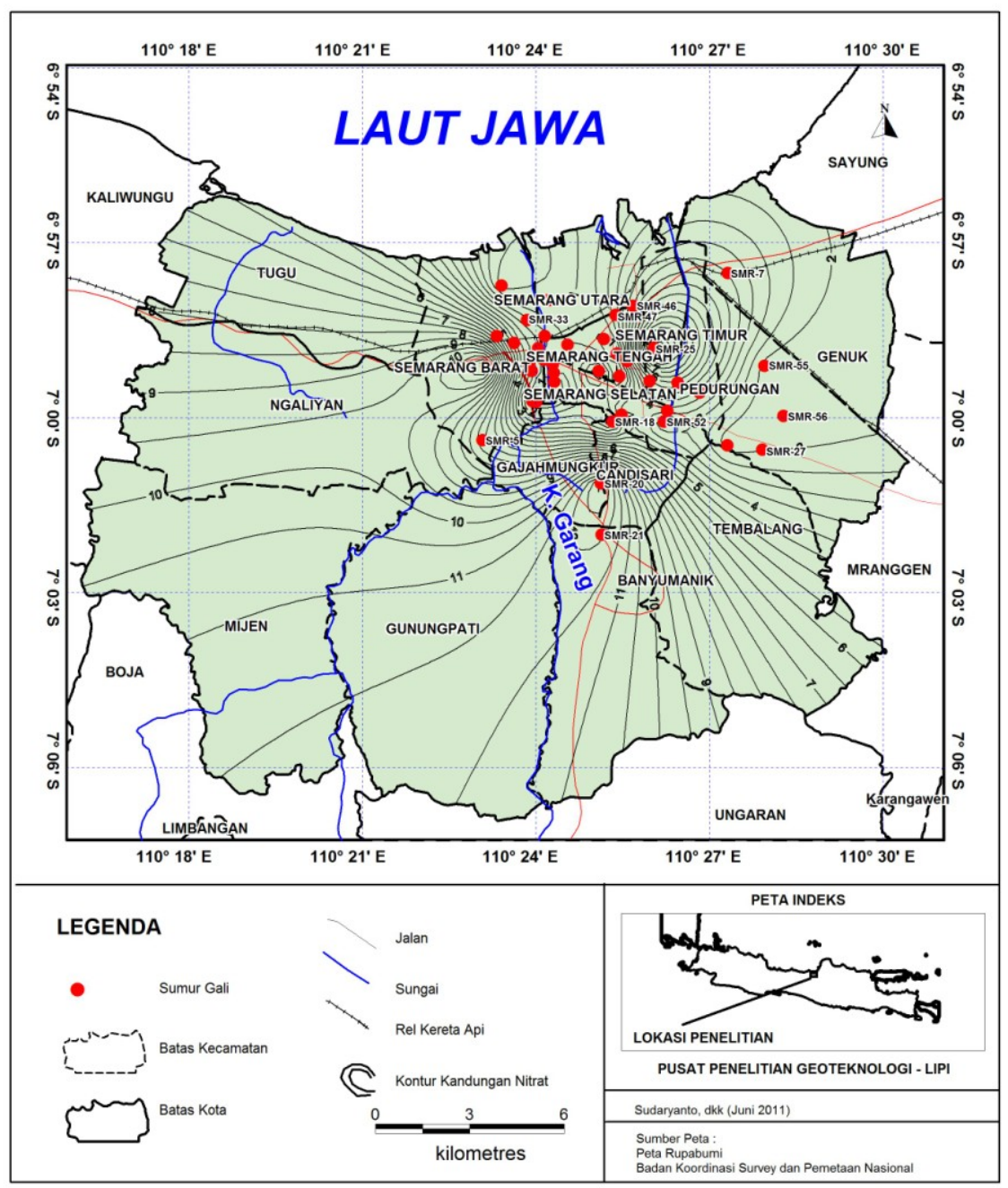

Gambar 6. Peta kontur kandungan nitrat pada airtanah dangkal. 
Tabel 2. Jumlah penduduk dan kepadatan penduduk 2010 di kota Semarang.

\begin{tabular}{|l|l|c|c|c|}
\hline \multirow{2}{*}{ No } & \multirow{2}{*}{ Kecamatan } & \multicolumn{2}{|c|}{ Tingkat Kepadatan Penduduk } & \multirow{2}{*}{$\begin{array}{c}\text { Kepadatan } \\
\text { Penduduk }\end{array}$} \\
\cline { 3 - 4 } & & $\begin{array}{c}\text { Luas } \\
\text { Wilayah }\end{array}$ & $\begin{array}{c}\text { Jumlah } \\
\text { Penduduk }\end{array}$ & \\
\cline { 3 - 4 } & & Km $^{2}$ & Jiwa & Jiwa per Km \\
\hline 1 & Mijen & 57,55 & 52.711 & 916 \\
\hline 2 & Gunungpati & 54,11 & 71.174 & 1.315 \\
\hline 3 & Banyumanik & 25,69 & 125.909 & 4.901 \\
\hline 4 & Gajah Mungkur & 9,07 & 62.413 & 6.881 \\
\hline 5 & Semarang Selatan & 5,93 & 85.309 & 14.391 \\
\hline 6 & Candisari & 6,54 & 80.224 & 12.267 \\
\hline 7 & Tembalang & 44,20 & 133.434 & 3.019 \\
\hline 8 & Pendurungan & 20,72 & 171.599 & 8.282 \\
\hline 9 & Genuk & 27,39 & 85.877 & 3.135 \\
\hline 10 & Gayamsari & 6,18 & 74.748 & 12.101 \\
\hline 11 & Semarang Timur & 7,70 & 80.433 & 10.446 \\
\hline 12 & Semarang Utara & 10,97 & 127.170 & 11.593 \\
\hline 13 & Semarang Tengah & 6,14 & 73.174 & 11.918 \\
\hline 14 & Semarang Barat & 21,74 & 159.946 & 7.357 \\
\hline 15 & Tugu & 31,78 & 27.846 & 876 \\
\hline 16 & Ngaliyan & 37,99 & 115.466 & 3.039 \\
\hline
\end{tabular}

Sumber data : Bappeda dan BPS Kota Semarang, 2011.

Untuk sumur gali di Petelan (SMR-25) dengan $\mathrm{pH} 7,26$ pada kedalaman muka air tanah $0,55 \mathrm{~m}$ dmt mempunyai kandungan nitrat $10,61 \mathrm{mg} / \mathrm{l}$, hasil penjelasan penduduk setempat bahwa muka air sumur sangat tergantung dari selokan (sungai) di sebelah timurnya yang berjarak kurang lebih $30 \mathrm{~m}$ dari sumur gali, ini menunjukkan bahwa polutan nitrat di pengaruhi oleh kondisi air sungai tersebut dan lahan di daerah ini merupakan urugan.

Dari hasil analisis conto airtanah yang telah di plot ke peta Gambar 6, dari sumur dangkal yang diambil dari wilayah kota lama Semarang yang berada pada akuifer endapan Kuarter tidak menunjukkan nitrat yang tinggi, sedangkan dari sumur dangkal sebelah selatan kota Semarang di vila-vila (Tanah putih dan Simongan) yang berada pada akuifer Formasi Damar di beberapa titik conto menunjukkan kandungan nitrat yang tinggi hingga melampui batas yang diperbolehkan. Dari nilai infiltrasi di kota lama Semarang pada akuifer endapan Kuarter termasuk kategori sedang dengan nilai kecepatan infiltrasi antara 24,628 cm/jam - 28,025 cm/jam, sedangkan infiltrasi di daerah selatan Semarang pada Formasi Damar termasuk katagori sedang sampai cepat dengan nilai infiltrasi antara 39,066 $\mathrm{cm} / \mathrm{jam}$ - 47,558 cm/jam. Tidak diketemukan kandungan nitrat yang tinggi di kota lama Semarang yang mulai dibangun tahun 1705, karena menurut Delinom et al., (2011), menjelaskan bahwa lapisan batuan pasir lempungan pada endapan Kuarter mempunyai kemampuan sebagai media penyerap polutan nitrat yang baik. Berbeda pada akuifer Formasi 
Damar pada batulempung, tufa dan breksi tidak mempunyai kemampuan menyerap polutan nitrat dan bersifat poros sehingga menjadi media meluluskan nitrat yang baik. Khusus di kota Semarang, kondisi ini mencerminkan bahwa umur permukiman tidak selalu berhubungan erat dengan tingginya kandungan nitrat karena karakter litologi berperan sebagai penyerap.

Seiring dengan kecepatan pembangunan di kota Semarang, jumlah penduduk pada tahun 2010 telah mencapai 1.527.433 jiwa atau dengan kepadatan penduduk 4.087 jiwa per $\mathrm{km}^{2}$. Keterkaitan antara kepadatan penduduk di kota Semarang (Tabel 2) dengan tingginya nitrat (Gambar 5), bahwa di kota Semarang yang terdiri atas 16 wilayah kecamatan kandungan nitrat diatas $10 \mathrm{mg} / \mathrm{L}$ terdapat di 5 kecamatan yaitu; di kecamatan Semarang Barat dengan kepadatan penduduk 7.357 jiwa per $\mathrm{km}^{2}$ terdapat di SMR13 (Karangsawo) dan SMR-14 (Sampokong), di kecamatan Semarang Selatan kepadatan penduduk 14.391 jiwa per $\mathrm{km}^{2}$ terdapat di SMR17 (Peleburan) dan SMR-19 (Tegal sari), di Kecamatan Candisari kepadatan penduduk 12.267 jiwa per $\mathrm{km}^{2}$ terdapat di SMR-18 (Genuk Krajan) dan SMR-20 (Jangli Tlawah), di kecamatan Bayu Manik kepadatan penduduk 4.901 jiwa per $\mathrm{km}^{2}$ terdapat di SMR-21 (Jatigaleh) sedangkan di kecamatan Semarang Tengah kepadatan penduduk 11.918 jiwa per $\mathrm{km}^{2}$ terletak di SMR-25 (Petelan Selatan). Semua lokasi yang mempunyai tingkat pencemaran nitrat tinggi semuanya terletak di tinggian bagian selatan dan Timur kota Semarang yang secara geologi masuk pada Formasi Damar (Gambar 6), kecuali di Petelan Selatan SMR-25 terdapat di tengah kota pada permukiman padat.

Ada hubungan antara kepadatan penduduk dengan tingginya nitrat terlihat di tiga kecamatan yaitu; di Semarang Tengah, Candisari dan Semarang Barat dengan kepadatan penduduk antara $11.918-14.391$ jiwa per $\mathrm{km}^{2}$ di beberapa titik conto mempunyai kandungan nitrat tinggi antara 10,61 mg/l - 13,25 mg/l. Didua kecamatan Banyumanik dan Semarang Barat dengan kepadatan penduduk antara $4.901-7.357$ jiwa per $\mathrm{km}^{2}$ di beberapa titik conto mempunyai kandungan nitrat tinggi antara 12,09 mg/l - 12,11 $\mathrm{mg} / \mathrm{l}$, sedangkan di kecamatan Semarang Utara, Semarang Tengah dan Gayamsari tidak nampak adanya kandungan nitrat yang tinggi, ini menunjukkan bahwa tidak selalu kepadatan penduduk ada hubungan langsung dengan tingginya nitrat, tetapi berkaitan dengan karakter litologi wilayah dimana conto airtanah diambil.

\section{KESIMPULAN}

Di kota lama Semarang yang dibangun sejak tahun 1705 yang berada pada akuifer endapan Kuarter tidak diketemukan nitrat yang tinggi, sedangkan di wilayah permukiman dan vila-vila (Tanah putih dan Simongan) yang dibangun sejak tahun 1942-1976 yang berada pada akuifer Formasi Damar di beberapa titik conto menunjukkan kandungan nitrat yang tinggi hingga melampui batas yang diperbolehkan (10 $\mathrm{mg} / \mathrm{L}$ ). Tidak diketemukannya nitrat yang tinggi di kota lama Semarang karena lapisan batuan pasir lempungan berfungsi sebagai media penyerap nitrat yang baik, sedangkan di wilayah permukiman dan vila-vila batuan bersifat poros berfungsi sebagai media meluluskan nitrat. Kondisi ini mencerminkan bahwa umur permukiman tidak selalu berhubungan erat dengan tingginya kandungan nitrat karena karakter litologi berperan sebagai penyerap atau meluluskan nitrat.

Hubungan antara kepadatan penduduk dengan tingginya nitrat di kota Semarang menunjukkan bahwa di tiga kecamatan dengan kepadatan penduduk antara $11.918-4.391$ jiwa per $\mathrm{km}^{2} \mathrm{di}$ beberapa titik kandungan nitrat antara $10,61 \mathrm{mg} / \mathrm{l}$ $-13,25 \mathrm{mg} / \mathrm{l}$ dan di dua kecamatan dengan kepadatan penduduk antara 4.901-7.357 jiwa per $\mathrm{km}^{2}$ di beberapa titik kandungan nitrat antara $12,09 \mathrm{mg} / \mathrm{-}$ 12,11 mg/l. Untuk di kecamatan Semarang Utara, Semarang Tengah dan Gayamsari tidak nampak adanya kandungan nitrat yang tinggi. Hal ini menunjukkan bahwa tidak selalu kepadatan penduduk berhubungan langsung dengan tingginya nitrat, tetapi ada kaitannya pula dengan karakter litologi di wilayah dimana conto air diambil.

\section{UCAPAN TERIMA KASIH}

Pada kesempatan ini, penulis mengucapkan terimakasih kepada Prof. Dr. Robert M. Delinom, Drs. Dadan Suherman, Dr. Sc. R. Fajar Lubis, Dadi Sukmayadi dan Alfi Rahmadani atas bantuannya selama penelitian dan penyusunan 
tulisan ini. Ucapan terima kasih disampaikan pula kepada Bapak Rudy Suseno, ST. MT, staf Dinas Pertambangan dan Energi Povinsi Jawa Tengah, serta seluruh rekan-rekan yang telah banyak membantu dalam pelaksanaan penelitian di Semarang. Kegiatan penelitian ini dibiayai dari dana DIPA Tematik tahun 2010 dan 2011.

\section{DAFTAR PUSTAKA}

Arifin, M. B dan Wahyudin., 2000. Penyelidikan Potensi Cekungan Airtanah Semarang dan Cekungan Airtanah Ungaran, Jawa Tengah. Direktorat Geologi Tata Lingkungan, Dirjen Geologi dan Sumberdaya Mineral, Departemen Pertambangan dan Energi. Bandung.

Delinom, R. M., Sudaryanto., Wibawa, S., Lubis, F. R., Gaol, K. L., Rusydi, A. F., 2011. Model Pergerakan dan Sumber Pencemar Airtanah dangkal di daerah Semarang. Program Penelitian dan Pengembangan Iptek. Pusat Penelitian Geoteknologi. Lembaga Ilmu Pengetahuan Indonesia (Tidak dipublikasikan).

Effendi, H., 2003. Telaah Kualitas Air Bagi Pengelolaan Sumber Daya dan Lingkungan Perairan, Penerbit Kanisius. Yogyakarta.

Hammer, M. J, \& MackKichan, K. A., 1981. Hydrology and Quality of Water Resources, John Wiley \& Sons Inc., Singapore.

Hendrayana, H., 2010. Derasnya Urbanisasi dan Pengelolaan Sumberdaya Airtanah. Harian Ekonomi Neraca. Bataviase.co.id. http://bataviase.co.id diunduh 2- Februari2011.

Tang, C., Azuma, K., Iwami, Y., 2004. Nitrate Behaviour in the Groundwater of Headwater Wetland, Chiba, Japan. Hidrological Processes, Published online Wiley InterScience.

Kendall, C. 1998. Tracing nitrogen sources ang cycling an catchment. In Kendall $\mathrm{C}$, We Donne JJ, editors, Isotop Tracers in
Catchment Hydrology. Elsevier. Science B.V, The Netherland;

Min, J-H., Seong, T. Y., Kangjoo, K., Hyoung, S. K dan Dong, J. K., 2003. Geologic on the chemical behavior of nitrat in river side alluvial aquifers, Korea. Hydrological Processes, 17, 1197-1211. John Wiley \& Sons, Ltd.

Notodarmojo, S., 2005. Pencemaran Tanah dan Airtanah, Penerbit ITB, Bandung.

Kendall, C., 1998. Tracing nitrogen source and cycling in catcment. Dalam Ohte N, Nagata T dan Yosshimizu C, Nitrogen and Oxygen isotop measurement of nitrat to survey the sources and transformation of nitrogen load in river. Proceedings, Tsukuba, Japan.

Purwanto, L. M. F., 2005. Kota Kolonial Lama Semarang (Tinjauan Umum Sejarah Perkembangan Arsitektur Kota). Dimensi Teknik Arsitektur Vol.33. No.1. Jurusan Teknik Arsitektur, Fakultas Teknik Sipil dan Perencanaan. Universitas Kristen Petra.

Bappeda dan Badan Pusat Statistik (BPS) Kota Semarang., 2011. Semarang Dalam Angka.

Sudaryanto dan Suherman, D., 2008. Degradasi Kualitas Airtanah Berdasarkan Kandungan Nitrat di Cekungan Airtanah Jakarta. Riset Geologi dan Pertambangan. Vol 18, No2, 61-68

Sihwanto dan Iskandar, N., 2000. Konservasi Airtanah Daerah Semarang dan Sekitarnya. Direktorat Geologi Tata Lingkungan, Dirjen Geologi dan Sumberdaya Mineral, Departemen Pertambangan dan Energi. Bandung.

Umezawa,Y., Hosono, T., Onodera, S., Siringan, F., Delinom, M. R dan Taniguchi., 2007. Sources of nitrat and ammonium contaminations in groundwater at developing Asian Megacities, LIPI Press. 